\title{
Organization of Education Using Modern Distance Learning Technologies in the Context of the COVID-19 Pandemic (on the example of Russian law schools)
}

\section{Организация обучения с помощью применения современных дистанционных образовательных технологий в условиях пандемии COVID-19 (на примере российских юридических вузов)}

Received: september 28, 2020

\begin{abstract}
The purpose of the article was to find the key problems of transferring the educational process into a distance form, and options for their solution. The changes that have taken place in the world over the past year have posed new challenges for society to which it should have been able to react. The sphere of education found itself in a rather difficult situation. It had to be reorganized in a short time and began to function in a remote communication mode.

The author's methodology was based on an empirical study (a survey of teachers and students) to determine the degree of their readiness for a global transition to distance learning. Moreover, sociological, systemic analysis and synthesis scientific methods were used.

During the study, the authors have concluded that neither teachers nor trainees were ready for the transformation that took place in the field of education. The problems faced by the participants in the educational process are both technical and psychological. In the technical sphere, there was an acute shortage of equipment used by trainees in the
\end{abstract}

Accepted: october 31, 2020

Written by:

Leonid T. Borodavko ${ }^{18}$

https://orcid.org/0000-0002-3017-7507

SPIN-code: 9281-1464

Nikolay N. Silkin ${ }^{19}$

https://orcid.org/0000-0002-9979-8037

SPIN-code: 7166-5798

Alexander V. Shakhmatov ${ }^{20}$

https://orcid.org/0000-0001-9375-7317

SPIN-code: $6783-1708$

Olga V. Chelysheva ${ }^{21}$

https://orcid.org/0000-0001-7373-7933

SPIN-code: $9698-0790$

\section{Аннотация}

Целью статьи стал поиск ключевых проблем перевода образовательного процесса в дистанционную форму, и вариантов их решения. Изменения, произошедшие в мире за последний год, поставили перед обществом новые вызовы, на которые оно должно было суметь отреагировать. В довольно сложной ситуации оказалась сфера образования, которой пришлось в сжатые сроки перестроиться и начать функционировать в режиме удаленного общения.

В основе авторской методики было эмпирическое исследование (опрос преподавателей и обучающихся) на предмет определения степени их готовности к глобальному переходу на дистанционные формы обучения. Кроме того, применялись социологический, системный методы, методы анализа и синтеза.

В ходе исследования авторы пришли к выводу о том, что к произошедшей в сфере образования трансформации оказались не

\footnotetext{
${ }^{18}$ Doctor of pedagogical Sciences, Saint Petersburg University of the Ministry of internal Affairs of Russia, Russia

${ }^{19}$ Doctor of pedagogical Sciences, Saint Petersburg University of the Ministry of internal Affairs of Russia, Russia.

${ }^{20}$ Doctor of law, Saint Petersburg University of the Ministry of internal Affairs of Russia, Russia.

${ }^{21}$ Doctor of law, Saint Petersburg University of the Ministry of internal Affairs of Russia, Russia.
} 
educational process. In addition, the lack of Internet traffic provided made it difficult to exchange information between participants in the educational process.In the psychological sphere, the difficulties have boiled down to the fact that in the new environment the role and degree of responsibility of trainees have increased significantly, which was highly negatively assessed by them. Teachers of the older age group have turned out to be practically unprepared for mastering new methods using technical teaching means. The learning process was mainly reduced to self-preparation of students, during which they were offered to read lecture materials, self-test, independent problem solving and other tasks. At the same time, the interaction between a teacher and trainees was minimized. Some options for the implementation of techniques were proposed in the article. They will help in the future to grade a number of problems, increase the degree of interaction between the teacher and students, making remote learning more convenient and comfortable for many.

Keywords: distance forms of interaction, new learning technologies. готовы ни преподаватели, ни обучающиеся. Проблемы, с которыми столкнулись участники образовательного процесса, носят как технический, так и психологический характер. В технической сфере наблюдалась острая нехватка оборудования, используемого обучающимися в образовательном процессе. Кроме того, нехватка Интернет-трафика, предоставляемого провайдерами, сильно затрудняла обмен сведениями между участниками образовательного процесса. В психологической сфере трудности сводились к тому, что в новой обстановке существенно возросла роль и степень ответственности обучающихся, что было оценено ими в большой степени негативно. Преподаватели старшей возрастной группы оказались практически не готовы к овладению новыми методиками с использованием технических средств обучения. Процесс обучения преимущественно был сведен к самоподготовке обучающихся, во время которой им предлагалось чтение материалов лекций, самотестирование, самостоятельное решение задач и выполнение иных заданий. При этом взаимодействие между преподавателем и обучающимися было минимизировано. В статье были предложены некоторые варианты реализации методик, которые помогут в будущем нивелировать ряд проблем, повысить степень взаимодействия между преподавателем и обучающимися, сделав удаленное обучение для многих более удобным и комфортным.

Ключевые слова: дистанционные формы взаимодействия, новые технологии обучения.

\section{Introducción}

The rapid spread of the especially dangerous coronavirus infection COVID-19 forced the whole world to reconsider its previous views on the organization of all public events, including the education process. Many people were simply not ready for the transition to remote forms of interaction in some areas of our usual life. Although it must be admitted that remote forms are developing quite rapidly. There are new opportunities for converting traditional forms of communication into contactless, remote, etc.

One of the first spheres to actively introduce remote forms of interaction was television. Many talk shows and television programs have switched to the format of video conferencing, which allows communication with interviewers via remote access. At the same time, television quickly included in the broadcasting network new auxiliary educational programs that allow schoolchildren to master the curriculum in the absence of the opportunity to attend school in person.

Unlike television, which is aimed at a wide range of TV viewers, the teaching staff of educational organizations must consider the interests of specific trainees, as well as the individual characteristics of the educational program of and, especially, universities have faced with huge problems. their educational institution. In this case, schools 


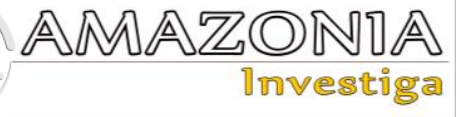

\section{Theoretical basis}

The need to introduce distance learning into the educational process has been discussed many times in the scientific literature. In 2004 V. Kanaev wrote about this: "Theoretically, Russia was ready to implement distance education and training along with other developed countries of the world. But the widespread introduction of distance technologies into educational practice in Russia was hampered by such factors as: the high cost of developing and maintaining software for educational and methodological sets of distance learning; the lack of technical and human resources in most educational institutions to support distance education systems; lack of methodological developments in the field of information content for distance education courses; the lack of personal computers and access to the Internet for potential consumers of distance education services" (Kanaev, 2004). It is worth noting that the set of difficulties in general has not changed much over the past 16 years. Their essence boils down to the following.

First of all, university professors have faced with the problem of lack of uniform approaches to the choice of platforms and computer programs for training in conditions when such a decision had to be made urgently. The low demand in the "PreCOVID-19" period for distance forms of interaction between the teacher and the trainees led to the fact that during the pandemic it was necessary to urgently select means and methods of remote communication. Some of the platforms and programs were "rejected" by the Ministry of Science and Higher Education of the Russian Federation for political reasons, others - due to the inconsistency with functional needs. As a result, for a long time this issue was actually left "at the mercy" of the teachers themselves, who, at their own peril and risk, had to choose and independently master certain new technologies, platforms and programs that would satisfy their pedagogical needs. "In a social sense, the adoption of a new technology is to consolidate the usefulness of the device and expand the horizon of awareness of the opportunities that have arisen among various groups of users. That is the rooting of social rules and requirements that did not exist before that create a new everyday life" (Sergeeva, 2019). For a fairly long period of time, such a new reality has become the forced remote form of interaction between the teacher and students.

Secondly, if in large cities the problem of equipping home computer equipment was not so obvious, then in smaller settlements many students simply could not physically connect to platforms and programs selected by educational organizations due to the lack of the necessary equipment (computers, laptops, tablets, smartphones).

Thirdly, the problem of poor Internet coverage of a huge part of the country became apparent. Even in the presence of a training platform, programs, technology, the simultaneous connection of all students and them led to a collapse when communication was not established due to server overload. Many students complained about the lack of home wired Internet, about the fact that they have to use a mobile phone that does not cope with the necessary tasks.

Fourthly, previously developed teaching materials could hardly be used without adaptation in distance learning. Often, for their implementation, special knowledge in the field of computer technology was required, which the teachers simply did not possess. Nevertheless "the modern technologized media environment makes increased demands on the level of digital literacy - a set of knowledge and skills that are necessary for the safe and effective use of digital technologies and Internet resources" (Efanov et al, 2020,). Therefore, the educational process, in the absence of appropriate skills among teachers, was reduced to the independent study of lecture materials, printed in a text editor, by the students on the instructions of the teachers, to self-testing, to the independent solution of problems in specialized subjects, which actually led to the leveling of the teacher's role. But the implementation of "remote forms of interaction" presupposes the presence of this very "interaction". In practice, the objectively developed unpreparedness of the teaching staff of educational organizations to work with digital information technologies and sometimes pronounced nihilism, that is, unwillingness to master modern teaching methods, coupled with the bureaucratic nature of the educational process, that is, excessive paperwork and a huge mass of all kinds of reports, have endangered frustrating the entire educational process. The last feature, perhaps the most significant, is also noted by modern scientists: "One of the serious problems today is the impossibility of abandoning the formation and processing of a huge number of paper documents, even if there is an electronic document flow in the university" (Shabanov, Rastjagaev, 2020).

For the sake of fairness, it should be said that the existing platforms, programs and teaching aids 
are now quite sufficient to ensure the quality of distance learning that is quite acceptable in all respects. Technical issues are also solvable if there is interest from the administrations of educational organizations and the trainees themselves. The main difficulty was precisely in the swiftness, hasty transition from traditional forms of education to distance learning. Evolutionarily, sooner or later, humanity would still come to the conclusion that remote communication would partially supplant personal.This is already in demand today by all of us in the household sphere. We actively use instant messengers, platforms and programs for video conferencing, etc. in the absence of the opportunity to be close to family and friends.

\section{Methodology}

The empirical research we carried out was intended to confirm or refute our arguments.In March-May 2020, we conducted a remote survey at the universities of Saint-Petersburg, Kaliningrad and Volgograd. The task of our survey was to find out the degree of readiness of teachers and trainees to master remote forms of interaction (teachers and trainees' level of mastering the skills of collecting computer information, processing and analyzing it, using Internet resources for these purposes in educational activities). The survey was attended by 58 teachers and 372 trainees of law schools and faculties, representatives of civil and departmental educational organizations.

Among the surveyed trainees there were 50.5\% of young women, $49.5 \%$ of young men. By age, students were distributed as follows: $24.5 \%$ - at the age of $17,25 \%$ - at the age of $18 ; 30.5 \%$ - at the age of $19,2.5 \%$ - at the age of $20,9.5 \%$ - at the age of $21,8 \%$ - at the age of 22 . Among the teachers there were $57 \%$ women, $43 \%$ men. By age, teachers were distributed as follows: 25-29 years old $-8 \%, 30-39$ years old $-37 \%$, 40-49 years old $-29 \%, 50$ years and older $-26 \%$.

The bulk of the respondents $(87.5 \%)$ are students of specialty programs, others $(12.5 \%)$ are bachelors. This is a completely natural result, since the number of students in Russian MIA departmental universities for specialty programs is much higher, namely, departmental trainees made up the bulk of the respondents.

As a result of the study, it turned out that during the training video conferencing means were used mainly. Such means make it possible to bring remote forms of communication as close as possible to traditional ones. At the same time, the opinions of trainees and teachers on this issue significantly have diverged. The overwhelming majority of teachers $(68 \%)$ said that face-to-face communication, even through a screen, cannot be replaced by any other form of interaction such as viewing lecture notes, educational videos, etc. Trainees $(77 \%)$ noted that they would prefer such forms of distance learning, which allow them to independently choose the place and time of acquaintance with the educational material. It is not always convenient for them to be "tied" to the means of communication at a strictly defined time for which the videoconference is assigned. A comparative analysis of the results of our study with similar results reached by other scientists (Bannyh, 2016) showed a general trend towards a gradual decrease in students' need for traditional forms of interaction between a teacher and students.

Within the framework of the study, the role of Internet resources in preparing for learning with trainees and for work with teachers was established.There were practically no young people who would be able to do without the daily use of gadgets for communication (99\%). In $83 \%$ of cases, Internet resources were the only source of information needed in the educational process for both teachers and students. Scientists also pay attention to this: "An increase in the share of electronic resources in the educational process becomes quite objective and natural due to the availability of information and the promptness of its extraction" (Bannyh, 2016). However, there is noticeable resistance among the older generation of teachers. Some respondents $(7 \%)$ rarely resorted to the Internet, preferring traditional printed publications. Among the trainees, there were no those who found an alternative to the Internet for finding educational information. And this is quite understandable. Everyone is interested in quickly obtaining information, which in $99 \%$ of cases comes from Internet sources, including through reference search engines, mail programs and instant messengers. Preparation for classes involves the study of literature, the search for which is greatly facilitated by the use of electronic and virtual libraries, communication with the teacher and fellow students.

At the same time, some problems have been identified among the students: a weak ability to navigate the world of information and computer technologies, inability to process information and express their own thoughts. The difficulties of distance work for teachers directly depended on their age. The younger the teacher was, the more adaptable he was to changes related to 


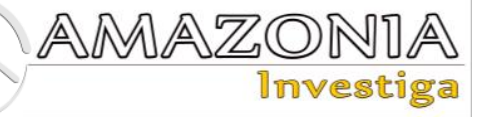

information culture, the faster he perceived and adopted new forms and practices of working with information. Teachers of older age categories turned out to be less adaptive and adapted to such changes. They showed conservatism in the forms and methods of teaching.

\section{Results and discussion}

We have to admit that in the field of education, such a rapid and revolutionary transition has led to numerous problems of both a technical nature and a psychological nature. The problems have jeopardized the implementation of the main principle: "Personality development acts both as a fundamental goal of public policy and as a result of the activities of an educational organization" (Vavilina, Efremova, 2020).

Technical difficulties were caused by the simultaneous introduction of a remote communication mode not only in educational, but also in the vast majority of other areas of our life. However, as we found out, this transition was much easier for young people than for the older generation, since young people are more predisposed to "mobility based on digital content: study or work at a distance" (Kravchenko, 2019).

On the one side, the rapid transition to "remote access" has led to an exuberant demand for smartphones, tablets, laptops and PCs used for work. So, "according to experts, from January to June 2020 inclusive, Russians purchased approximately 1.5 million devices. This is an impressive bigger on $38 \%$ compared to the same period in 2019" (Kasmi, 2020).

On the other side, in the first three months of 2020, there was a significant gap between supply and demand in the global PC market. "Shipments for Q1 2020 (53.7 million units) 8\% below the 2019 level, while the demand for desktop PCs, laptops and workstations has grown significantly due to the global transition of hundreds of millions users to remote employment and distance learning" (Belous, 2020). Manufacturers of IT technology weren't ready for such a significant increase in demand for their products. The increased demand has led to higher prices. At the same time, manufacturers didn't rush to increase production, fearing that oversaturation of the market with PC, laptops, tablets and smartphones would subsequently provoke a decrease in sales, and, therefore, losses for them.
The result of the listed problems was a real difficulty with purchasing such a technique that would allow students to receive a quality education.

However, in addition to technical problems, psychological ones were added. Neither lectures (teachers) nor students were ready for the transition to distance learning.

The point is that the historically - "teacher" (in the broadest sense of the word) - was perceived by students as one of the few information sources, as a person who transmitting knowledge and skills received from their ancestors. In a family for children, the role of teachers was played by parents who pass on everyday skills to the next generation. In other areas, these were people with authority, achievements in any area. Except teacher personally, as a standard for others, as an example to follow, over time, another more or less accessible channel for obtaining and storing information appeared these are written sources - books. There was no other way for people to get the required information.

Moreover, from a certain time, the state took control of process of training teachers, their qualification, approving them certain diplomas, certificates, etc.

With the advent and introduction into our life of digital technologies, the Internet, as a universal channel of communication, obtaining information, the image of the teacher began to gradually "blur". Today, everybody is trying to play this role - "bloggers and other subjects who sometimes do not understand anything about what they are trying to teach others" (Alekseeva \& Volobueva, 2013). However, blogging shouldn't be "written off", since it can be used by professionals in their field and for quite positive purposes as a type of activity, tool in social and communication technology. "The differences between these forms of blogging are due not only to a set of methods and / or techniques used by members of blogosphere, but, first of all, to their goals and objectives. It can be used for: expressing an opinion on certain topics, events and subjects, attracting to its opinion attention of other blogosphere members, information presence in blogosphere, image positioning, as well as communication interaction with the audience" (Bliznjak \& Gerasimov, 2017). Although it can be quite difficult to distinguish a real professional from a swindler. There are no guarantees of the quality of the presented material in such sources of information. The 
Internet, with its many resources, has often become a conglomerate of false knowledges. Appeared an illusion of acquiring knowledge in a different from the traditional way. The "systematization of knowledge, which is one of the essential features of scientific knowledge" (Kareev, 2020) begin to disappear. The emerging channels for acquiring information in the absence of a guiding role of the teacher don't allow students to get "a holistic idea of specific ways to achieve educational goals, and many opportunities, with all the availability of information, remain unrealized" (Biricheva, 2019).

Nevertheless, the Internet is a tool that can and should be used for the benefit of learning. If the process of introducing distance learning technologies was evolutionary, then teachers should be able to progressively, sooner or later, achieved all the relevant methods and technologies in the required volume. Current revolutionary process, not everyone has succeeded. Is this good or bad? This is rightfully. So, with the development of modern technologies, the role of the lecturer (teacher) in educational process is really changing: if before the lecturer (teacher) was the main source, leader, guide in the information flows, knowledge, skills, then now his role is often reduced to "directing to the exact industry, generalization of information already available to the trainees, correction, clarification of complex issues that caused difficulties" (Hodjakova, 2017). In fact, the teacher, has only update the material offered it to the student, prepare methodological aids (lectures, tasks, texts) suitable for distance learning, and control the correctness of assignments. Although the control function sooner become largely automated as well. For example, if you use the existing platforms for automated testing, then the lecturer (teacher) should only summarize the marks of students' knowledge. Many authors write about the benefits of computer testing. Thus, E. Baran, A. Yurkevich note: "Computer testing is an effective way to test knowledge, which is increasingly being used in education. One of its advantages is the minimum time spent on obtaining reliable control results, as well as obtaining results almost immediately upon completion of the test. First of all, the tests are distinguished by complete objectivity in assessing the student's knowledge, since in the traditional control of knowledge and in giving marks, the subjective opinion of the teacher may be an influencing factor. The possibility of using thematic tests for self-control and as a simulator of independent work, which takes on a new form and becomes controlled" (Baran \& Jurkevich, 2020). However, it should be remembered that computer testing doesn't replace traditional methods of teaching and control of knowledge and acts only as their essential addition.

Solving the problem can also be built in an automatic mode, but it will be more difficult, especially in legal and humanitarian disciplines, since it is required to take into account many factors in rapidly changing legislation, which are rather difficult to implement into computer algorithms.

The situation is even more complicated with the distance development of specific practical skills: firstly, special complex equipment is often required that cannot be provided to students at home (for example, for teaching forensic science - microscopes, spectrometers, etc.); secondly, training requires the personal participation of a lecturer (teacher) in setting up this equipment and demonstrating its properties; thirdly, the training process requires compliance with safety precautions, especially when it comes to working with substances that are hazardous, prohibited or restricted to civilian circulation (for example, in the production of explosives expertise, ballistic expertise, etc.). It is simply impossible to organize such training at home.

Consequently, the role of the teacher's interaction with the student in the educational process remains quite high, although it cannot be denied that in some areas it is still gradually decreasing. On the other hand, the role of the student personally is growing noticeably in obtaining knowledge, analyzing information, working with big data, which is not always successfully implemented by him. "The format of distance learning presupposes not only the territorial remoteness between the educational institution and student, but also an increase in the volume of student's independent work, which, according to consumers of educational services, significantly reduces the quality of the educational process" (Kotljarenko \& Simonova, 2020). But distance learning in the context of a pandemic has become not a voluntary choice of educational institution and students, but almost the only solution which allowed to continue the educational process. In this situation, lecturer (teachers) weren't ready to quickly adapt to the new format of communication and recognize the decline in the dominant role of direct communication in the learning process. The students weren't prepared for their increased role in acquiring knowledge, for responsibility for failure to complete tasks. Mutual lack of readiness passed to rather sad 


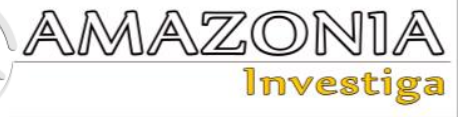

results. Although, in order to achieve success in the field of distance learning, it would be worthwhile to think about changing the very format of interaction between the teacher and students. Many scientists say about this: "On the one hand, the problems of the modern world require the practical implementation of original solutions based on the maximum use of nontraditional types of thinking; on the other hand, the creation and implementation of new products that are significant for society, which is impossible without understanding the real situational circumstances" (Borovinskaja, 2017). In the first instance, it would be worth revising the format of the lecture, abandoning the traditional manner of presentation by the lecturer of the material with which the students get acquainted for the first time. From a methodological point of view, it would be more correct in a distance mode to first provide students with the materials under study, and then conduct a "stream lecture", that is, a lecture in the video conferencing format, when the lecturer not only presents the material, but also communicates with each student, responds immediately to the emerging questions that students write in the live chat. Feedback is immediately established between the lecturer and the students, the lecturer checks the degree of understanding of the topic by the students. On the one hand, this format of the lecture lesson overlaps with the seminar (demonstration by students of the achieved level of theoretical training). On the other hand, it allows, within the framework of a seminar, to use other, more active forms of communication (a detailed conversation, a seminar-debate, exercises for independent thinking, etc.), to form "the skills of public online speaking, the ability to expand the volume of knowledge, to acquire skills of independent work" (Hodjakova \& Petrjakova, 2017).

For a practical lesson, the most preferable format would be the synchronous use of cloud services by the teacher and students (Fedorov, V., Fedorova, T., Kosiuta, M., Ahapova, K., Topal, A., 2020) We have already found out that practice training is the most difficult class for distance learning due to many technical difficulties. However, it is quite possible to develop practical skills in issues same app together and with the synchronous participation of the teacher and students. To do this, a single platform is installed on the devices of the training participants (smartphones, tablets, laptops, PCs), which allows you to synchronous log into a common server and, seeing all the participants, jointly carry out a common practical task. This does not require huge device resources of memory or CPU high performance. All processes take place on a remote server in the online storage.

\section{Conclusions}

Many researchers point a wide range of advantages of distance learning over the traditional method, since it "allows the user to acquire new or improve knowledge and skills." The student can choose the area of knowledge he is interested in, build and adjust the schedule of the online course, its duration, place of study, determine information technologies when studying the course. Online learning completely immerses the user in to the educational environment. He can watch and listen to lectures, complete assignments, consult with teachers and communicate with classmates due to the network connection. At the same time, students themselves determine when and how long to study" (Koval'chuk et al, 2020). "The strategy of combining the efforts of education institution through the establishment of online network interaction, which makes it possible to carry out the "division of labor" in the preparation of the methodological support for the courses disciplines" (Anisimov et al, 2018), requires a separate discussion.

The implementation of all the methods described by us would allow avoiding formalism in teaching during the spread of the especially dangerous coronavirus infection COVID-19. And in the future, in the long term, it would lead to the fact that in the pedagogical work would stay those professionals who can and want to accept the new realities of the educational process, as well as correspond to the modern level of development of scientific and pedagogical technologies. At the same time, the partial introduction of distance learning technologies even now would significantly increase the level of self-control and selfdevelopment among students who are capable of independent learning under the supervision of a teacher.

\section{References}

Alekseeva, A.P., \& Volobueva, E.V. (2013). Youth policy in the Russian Federation and its legislative regulation. Actual problems of the preliminary investigation: collection of scientific papers of the international scientific and practical conference (November 28, 2013, Volgograd). Volgograd: VA of the MIA of Russia, Vol. 1, pp. 198-202. 
Anisimov, A.P., Ryzhenkov, A.J., \& Serebryakova, A.A. (2018). Interuniversity integration on the basis of Network Interaction: Experience of Russia. Espacios, 39(25), pp. 32. Bannyh, G.A. (2016). Use of Internet technologies in university education: information competence and opportunities for its formation among students and teachers. Tomsk state university journal. Philosophy, Socialand Politicalscience, No. 33, pp. 15-24.

Baran, E.A., \& Jurkevich, A.A. (2020). Development of the computer testing process. Scientific and practical research, No. 1.1 (24), pp. 8-10.

Belous, M. (2020). The global demand for computers is growing, shipments are decreasing and then there will be a recession. crn.ru. Recovered from: https://www.crn.ru/news/detail.php?ID=144529 Biricheva, E.V. (2019). Involvement of young scientists in innovations, technological and industrial development of the country (case of the Institutes of the Ural Branch of the Russian Academy of Sciences). Sociology of Science \&Technology, vol. 10(4), pp. 125-160.

Bliznjak, R.Z., \& Gerasimov, I.A. (2017). Blogging as a technology of social and political communication: specification of concept and characteristic of heuristic opportunities. Tomsk state university journal. Philosophy, Socialand Political science. No. 40, pp. 222-231.

Borovinskaja, D.N. (2017). Creative thinking: the main directions of research. Tomsk state university journal. Philosophy, Socialand Political science. No. 40, pp. 22-31.

Efanov, A.A., Budanova, M.A., \& Judina, E.N. (2020). Rate of student and teacher's digital literacy: comparative analysis. Vestnik RUDN. Series: Social science, 20(2), pp. 382-393.

Fedorov, V., Fedorova, T., Kosiuta, M., Ahapova, K., \& Topal, A. (2020). Legal aspects of the use of cloud technologies. Amazonia Investiga, 9(28), pp. 296-302. https://amazoniainvestiga.info/index.php/amazo nia/article/view/1324

Hodjakova, N.V. (2017). Methodological approaches to the design of modern systemic legal education. Conceptual approaches to improving the Russian legal system: materials of the international scientific and practical conference (Volgograd, December 15, 2016). Volgograd: Publishing house of the Volgograd Institute of management, a branch of the Russian presidential Academy of national economy and public administration, pp. 292-295.

Hodjakova, N.V., \& Petrjakova, S.V. (2017). Personal development potential of E-learning. Ivzestia of the Volgograd State Pedagogical University, No. 8 (121), pp. 12-16.

Kanaev, V.I. (2004). Distance learning in civil society and law enforcement agencies. Innovation in education, No. 2, pp. 33-42.

Kareev, N.I. (2020). The General of Methodology of the Humanities. Sociology of Science \&Technology, 11(2), pp. 64-85.

Kasmi, E. (2020). Russians snatch from store shelves laptops, smartphones and PC countrywide. CNews. Recovered from: https://www.cnews.ru/news/top/2020-03-

31_rossiyane_rashvatyvayut_noutbuki.

Kotljarenko, Ju.Ju., \& Simonova, O.B. (2020). E-learning or distance learning. Kazan pedagogical journal, No. 3, pp. 75-83.

Koval'chuk, S.S., $\quad$ Garkusha, N.A., Medjankina, E.N., \& Muhina, Ju.N. (2020). Online learning: from the experience of foreign and Russian universities. Higher Education Today, No. 1, pp. 31-37.

Kravchenko, S.A. (2019). Digital risks, metamorphosis and centrifugal tendencies in youth environment. Sociological research, No. 10, pp. 48-57.

Sergeeva, O., \& Laktjuhina, E. (2019). Social aspects of digitalization of children's urban mobility. Journal of Social Policy Studies, 17(4), pp. 507-524.

Shabanov, G.A., \& Rastjagaev, D.V. (2020). University's digitalization: reality and expectations. Higher Education Today, No. 1, pp. 2-7.

Vavilina, N.D., \& Efremova, E.A. (2020). Risks of personal development in education. Tomsk state university journal. Philosophy, Socialand Political science, No. 55, pp. 175-184. 